\title{
Plagiarism and Academic Integrity
}

Nur Azlin Bahrul Zaman, Saiful Farik Mat Yatin, Nur Shurbaniah Saad, Siti Najwa Rashid, Yamin Kamis, Irwan Kamaruddin Abd Kadir, Wan Ab Kadir Wan Dollah

To Link this Article: http://dx.doi.org/10.6007/IJARBSS/v10-i11/8189

DOI:10.6007/IJARBSS/v10-i11/8189

Received: 28 September 2020, Revised: 26 October 2020, Accepted: 17 November 2020

Published Online: 30 November 2020

In-Text Citation: (Zaman, et. al., 2020)

To Cite this Article: Zaman, N. A. B., Yatin, S. F. M., Saad, N. S., Rashid, S. N., Kamis, Y., Abd Kadir, I. K., \& Dollah, W. Ab K.W. (2020). Plagiarism and Academic Integrity. International Journal of Academic Research in Business and Social Sciences. 10(11), 1138-1149.

\section{Copyright: (C) 2020 The Author(s)}

Published by Human Resource Management Academic Research Society (www.hrmars.com)

This article is published under the Creative Commons Attribution (CC BY 4.0) license. Anyone may reproduce, distribute, translate and create derivative works of this article (for both commercial and non-commercial purposes), subject to full attribution to the original publication and authors. The full terms of this license may be seen at: http://creativecommons.org/licences/by/4.0/legalcode

Vol. 10, No. 11, 2020, Pg. 1138 - 1149

Full Terms \& Conditions of access and use can be found at http://hrmars.com/index.php/pages/detail/publication-ethics 


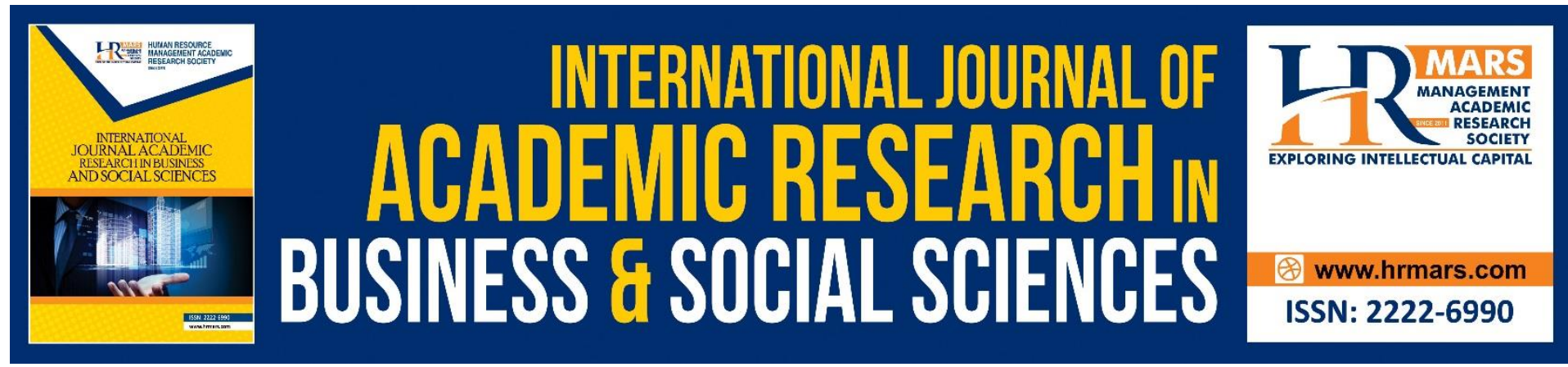

\title{
Plagiarism and Academic Integrity
}

\author{
${ }^{1}$ Nur Azlin Bahrul Zaman, ${ }^{1,2}$ Saiful Farik Mat Yatin, ${ }^{1}$ Nur \\ Shurbaniah Saad, ${ }^{1}$ Siti Najwa Rashid, ${ }^{1}$ Yamin Kamis, ${ }^{1}$ Irwan \\ Kamaruddin Abd Kadir, 'Wan Ab Kadir Wan Dollah \\ ${ }^{1}$ Faculty of Information Management, Universiti Teknologi MARA (UiTM) Selangor, \\ Malaysia \\ ${ }^{2}$ Members of Advanced Analytics Engineering Center (AAEC), UiTM Malaysia
}

\begin{abstract}
Issues of misconduct in educational institutions are never come to an end but keep intensifying and turn out to be more serious especially among students in a tertiary level institution. This paper discussed the reality of unethical act in educational institutions that often be seen and sometime making the circumstances as nothing happened. Several factors and consequences of plagiarism were considered while efficient approaches to cope with the issues are justified.
\end{abstract}

Keywords: Plagiarism, Dishonesty, Similarity Index, Academic Integrity.

\section{Introduction}

Plagiarism may happen in politics, educational institutions, organizations, and film production, among writers, designers and so forth. Plagiarism according to Cambridge Essential English Dictionary (2011), is defined as using another person's ideas or work and presenting as its own work. Wheeler and Anderson (2010) mentioned that academic integrity and respect of copyright are an enormous challenge to tertiary institutions globally which be the vital issue that plagiarism "circumvents the learning process". Supported by Wilkinson (2009), plagiarism is described as a spreading moral panic. It is visible as an offence to our common intellectualities and bring immoral for perpetrators (Wheeler and Anderson, 2010) and students are presently more inclined to participate in academic misconduct during their studies and are having perplexity on appropriate usage of information that they require help in academic writing skills (Marshall and Garry, 2005). How plagiarism is perceived and reality of academic misconduct in the tertiary level institution were discussed as follow;

\section{Electronic Sources of Information}

Growing of information society and mass media is another cultural diversity appears to be occurring. Wheeler and Anderson (2010) said that the blast of electronic sources of information made replicating simpler and considerably more fundamental to students' cultural and social experiences. With the accessibility to the internet and ease of copying, modifying, sharing, and disseminating assortment sources taken from the web, student cultivated their own search skills in leading non-scholastic research using platforms such as 
browser, community interacting sites, conversation platform, and etc. Students are most likely depending on the fast and easy sources through the internet in finding information and their behavior in referring to physical references especially when they need to go to the library is felt troublesome. Šprajc et. al., (2017) in their research, mentioned that Internet exposure primarily from information and communication technology is the main cause of breach of academic ethics. Plagiarism has not only being the major issue in an educational point of view, yet it is essential to consider that it can be caused by the factor of student's personal lives with a great impact from causal relationship between plagiarism and common aspects such as living in the information age, exposure of everyday Internet and its presence in the academic setting. The correlation between plagiarism and the Internet in an empirical research however did not show any results that proof of being the factors of academic misconduct, however in most studies done showed that, the ease of Internet access has been the main component which promotes the plagiarism among students. Technology has emerged as the main communication device that provides convenient and quick access to the ideas and information virtually and with the ease of copying presents the chances and options to mislead and manipulation to it.

\section{Intellectual Development}

Wheeler and Anderson (2010) also stress that the battle for intellectual development becoming the rational that makes plagiarism tempting for some students. Intellectual capabilities among the university student is varied which according to Marshall and Garry (2005), lack of fluency in expression, cultural factors, lack of academic writing skills, and poor language skills affect the idea of plagiarism.

Wilkinson (2009) in his research study reported that too much assessment (56\%) and desiring higher grade $(73 \%)$ were strong reasons for cheating besides student's set of attitudinal characteristics and their interrelationship like influences from acquaintance and sacred and honorable titles, anxiety to fail and punishments if spotted and the power of policies adverse in academic misconduct. Plagiarism may be caused by less understanding in doing referencing which high number of students who failed to distinguish normal citation practices when copying and quoting the words as well as confuse in using materials from other sources correctly (Marshall and Garry, 2005).

In most cases, academics don't seem to be involved in this artistic robbery, however, these lead students in missing out a great opportunity in learning since they are inadequate in enlisting material in a significant way which revoking them the chance in education, develop their study proficiency, knowledge and understanding (Wheeler and Anderson, 2010). Academics and institutional are at the central stage in providing knowledge of writing skills, the awareness of plagiarism to all students every year that could improve students' intellectual development over time, diminishing the plagiarism and produce excellent students with quality outcome of the assignments and research studies.

\section{Perceptions and Attitudes}

Personal integrity and credence of students are the concern of academic misconduct. Integrity and misconduct of intellectual property are associated to student perception whereby students showed they considered activities they engaged in themselves as being less critical than other who had not (Marshall and Garry, 2005). Students are attentive to the concerns it is possibly that academics would assume all forms of plagiarism seriously than they seem to. Academics and $65 \%$ students indicated that the act of cheating was 
unconscious and thought they were unlikely to be caught (Wilkinson, 2009). According to Marshall and Garry (2005), 55\% of academics and 56\% students assured they can discover cheating in student work however resulting to which $1^{\text {st }}$. year students has fewer self-assured and confusing in avoiding plagiarism than those in the third year.

Study done by Wheeler and Anderson (2010) reported that $49 \%$ of academics and $39 \%$ of students assumed that dishonesty in academic regularly corporates with "copying some paragraphs without citation" while Marshall and Garry (2005) reported that 94\% students understood that copying words without credit is a form of plagiarism. Similar behavior of copy and paste from electronic sources are considered either cheating or not cheating at all by more than $40 \%$ tertiary level students in the UAE which these attitudes are similar to the other student around the world (Wheeler and Anderson, 2010). Staff and students admitted that they most engage in cheating by copying a few parts of the article from a book and collaborating in another student's individual assignment however less engage in copying a whole content of an article from the internet and cheating during examination (Wilkinson, 2009).

Cheating in conducting research is common and interrelated with the number of years as a student, confidence in noticing plagiarism, and whether students warned of plagiarism. Different perceptions in plagiarism and attitudes of students and academics are also engaged with diversity of definitions of plagiarism in a different concept.

\section{Institutional Capabilities}

Academic institutions are aware of ethics in academic which students should pursue and they are currently standardizing their terminology in piloting a systematic punishment for plagiarism, however it remains imprecise to academics in understanding and regulating the terminology and the effectiveness of communicating the true definitions among academics and institutions (Marshall and Garry, 2005). Extensive definitions of plagiarism are used in different concept and applications, and according to Syahrani (2009), plagiarism meant different in culture of Chinese, Spanish and African which common debated in an academic circle. Supported by Wilkinson (2009), the terminology differences are also attached with the meaning and significance of the theory of plagiarism, cheating, and misconduct which arising confusion among academics and students and resulted in miscommunication and challenge designated educative programs in addressing academic misconduct in higher education.

Collective understandings of integrity and values in academic writing among academics and students is vital (Wheeler and Anderson, 2010) which less competence of institution lead to bad perception from students especially. Institutional capabilities are also depending on the provisions of punishments of plagiarism offences which English Speaking Background (ESB) students perceived that the University taking plagiarism seriously than Non-English Speaking Background (NESB) students do (Marshall and Garry, 2005).

\section{Penalties}

Punishments for offences of plagiarism depending on the seriousness of cheating in academic. It can be lighter and even severe reflecting to the institutional policies in classifying the forms of plagiarism to be compromised. Wilkinson (2009) listed among the penalties are counselling, demerit point, official reprimands, and failure in the subjects and to the most serious cases are expulsion from the course and university. $90 \%$ of academics reported warning for plagiarism had been given, however $9 \%$ of all students indicated they were 
warned, likewise they tended to favor "lighter punishments" as penalties for academic misconduct such as warnings and resubmission.

Lighter punishments in some other way that make the students less care of the plagiarism seriousness that they perceived. Marks will be merit although it is not as much as it should be. Students are likely to receive a warning with no loss of marks for the first and repeat offences of plagiarism conversely academics preferred the loss of marks (Marshall and Garry, 2005). Significant consequences of academic misconduct should be exposed among students along with the institution policies in plagiarism while academics required to take the issues seriously by complying the penalties established.

Cheating in academic issues are never end but keep ascending. These following factors may cause students to plagiarize and it is the responsibility of academics in identifying and preventing the issues from being a norm to students.

\section{a) Individuals}

Wheeler and Anderson (2010) mentioned that the students themselves in their previous institution, experienced different circumstances by which they are thought to memorize what they learnt, go for one answer with poor comprehension and non-transparent. They are also fronting judgments in social, and in between socially and economically deprived teachers. It is kind of culture shock for them when in tertiary education, they are expected and demanded for high academic skills such as resolving issues independently, critical thinking skills and much more important is the academic integrity. Supported by Marshall and Garry (2005), the student's attitudinal characteristics and their interrelationship are also the reason for students to plagiarized that academics required to assist students in moral support especially development of the students' intellectual. Plagiarism may also correlate with the individual's motivation that the students believe they can do the tasks given with their best of performance and enthusiastic to use any methods and approaches to accomplish their goal. Low-motivated students found that they get stuck in plagiarism as they have insufficient time, incompetence in coping with the amounts of assignment given, lack of knowledge of referencing and citing, have difficulties in finding the right materials and of creative thinking skills (Šprajc et. al., 2017). They claimed that poor explanations and overload assignments with insufficient time has unmotivated them. In contrast to high-motivated students, they are more concern on the importance of learning with high determination and strategies to achieve their goals as well as with projection of good behaviors prevents them from the breach of academic ethics. However, according to research done by Šprajc et al. (2017), there are no correlations between low and high motivated students with the plagiarism issue which it might be caused by the impact of student's self-efficacy on their academic performance.

\section{b) Pedagogical Approaches}

Academic institution especially, should focus on the techniques of collecting information online with high ethical principles and not only evaluating what is right and wrong. The primary focus is neither toward the technology problem not the resources availability, but orienting students to the proper field of education with the quality skills, abilities and competencies as well as with morality and ethical judgement when it comes to the issues of Internet and plagiarism (Šprajc et al., 2017). Besides that, by emphasizing teamwork in current approach, students are more incline in cheating depending on the assessment difficulty and based on unreasonable expectations of their abilities (Wheeler and Anderson, 2010). Supported by Wilkinson (2009), students plagiarized because of failure to comprehend 
and misunderstanding of different expectations, too much assignment, and cautious attempt to trick markers. While extensive concept and definitions of plagiarism also impacted students in fulfilling the course requirement and achieve the required standards (Wheeler and Anderson, 2010). Students with their own perceptions may think differently in perceiving what plagiarism is, that they admitted in cheating by collaborating in another student's individual assignment (Wilkinson, 2009).

A different perception of plagiarism by academics, turns student's view as an appropriate and strategic study. Unconstructed assignment made plagiarism easier by which stock answer cannot be copied from the internet. Institution should share the ideas and terminology of plagiarism where academics and students share the same concept and forwarding to the same approaches when undertaking assessment.

\section{c) Language and Academic Writing Skills}

Cultural acquisition of English as a second language (ESL) and English as Foreign Language (EFL) students has been cited as another contributed issue. Poor in paraphrasing and accidentally performed the misconduct might be interpreted as plagiarism. According to Wilkinson (2009), common plagiarism behaviors, student commented that they lack of basic skills of language by which they tend to copy the whole idea instead of rephrase. High number of students considered themselves doing the cheating by "copying several points of the passage" which caused by lack of skills in referencing with laziness in rephrase and give credits to the authors of the sources are considerable a crime in academic. Šprajc et al. (2017) stated that there are differences in methods of citation that students get into confusion in referencing the sources. It is proposed that academic world clarify the standardization of citation and provide the tools that provide the best and easier way to handle the electronic sources.

\section{d) Application of Institutional Policies}

Regarding to Wheeler and Anderson (2010), reasons of students committing academic misconduct are caused by blur and not transparent institutional policies in teaching true definitions of plagiarism and application of the concept in an academic. Formal definition of plagiarism provided to students in several cases varies consistent with the discipline, the context, and also the expectation of what's meant by general knowledge, institutional rules, and skilled codes of ethics. There are several reasons why academics are hesitant to report the wrong manners.

a) Severe punishments to students might be charged.

b) To avoid false accusations that probably challenge their own skilled standing.

c) Not interested in carrying out the detective role as to uphold good relationship between academics and student (UKEssays, 2003).

d) May not have sufficiently developed skills to detect plagiarism. It is a waste of their time and effort in disclose plagiarism and pursue investigations.

Interestingly, academics do check the plagiarism among students however there are numbers of them admitted they did not (Wilkinson, 2009). The skills in detecting plagiarism are practiced by academics however, students of first and second year felt that academics are not spotting and didn't take a look at for plagiarism. The skills sometimes perceived as not important and required to the academics however the perception may challenge the credibility of university institutions in providing assistance and concern in academic misconduct. 


\section{e) Lack of Understanding of What Constitute Plagiarism}

Plagiarism can also be recognized in several demographic and common factors such as age, sex, learning experience in university, and other factors such as social background which may impacted to the attitudes of academic misconduct.

a) Age: Plays an important role, which is according to the academic context, has been understood by Marshall (2005) that younger students are more cheating on assignments than older students. However, no significant indication that age affected the extent of plagiarism or the seriousness with which it was regarded was found.

b) Gender: According to Marshall (2002), gender factors are a challenging issue in the cause of plagiarism. Female respondents understand more the definition of plagiarism compared to male respondents. Giving men are more cheating in academia than women. It is found that $67 \%$ of female students are compared to $49 \%$ male students from the point of understanding the true meaning of plagiarism.

c) Culture and background: NESB students admitted to repetition material on the online than ESB students, that repetition was usually less serious by NESB students that didn't be attitudes to copyright violation for each teams. Lack of influence in expression usually will be excuse given by student however it's apparent that a spread of alternative cultural issue influence concepts regarding plagiarism and it conjointly clear that student from each speaking and different background have to be compelled to be motor-assisted in moving through the stage of fluency in their educational writing.

d) Relationship between violation of copyright and plagiarism: Correlations evaluation on the mind-set of students to do the violation of copyright and plagiarism and there is a big correlation between of the two units of scenarios. This indicates that whilst college students to view plagiarism from the internet as much less serious than plagiarizing from different sources, they will not exhibit preference to factors of intellectual property. This implies that the actual reason has to be placed elsewhere, might also arise from facilities, and no longer in terms of any substances provided electronically held differently. In typical students consider this no longer so serious: Only $1 \%$ of college students think about them as very serious and greater than $75 \%$ of students admitted to doing it. This in contrast with decrease rates to reproduction software and different plagiarism observed elsewhere.

Plagiarism surely will give impact to academic institutions and community and it is range from light to severe impacts;

\section{Punishment}

There are range of punishment in different institutions depending on the factor of apprehension on behavior form of misconduct in academic. Students who are plagiarizing trapped, in some academic restrictions, institutions might also include decrease grades, failed guides or dismissals from tutorial major. According to UKEssays (2003), four different discipline actions towards cheating in academic are marks reduction, subject fail, low merits in all courses, and failing the students in faculty. Students will get hold of severe sentences if they are spotted in plagiarism. Plagiarism is treated as a serious educational sanctity issue in tertiary level education institutions by emphasizing students on the seriousness engaging in cheating. Students who frequently committed in plagiarism are worthy of action of severe punishments. However, factors of academics in treating the seriousness of plagiarism might be the issue where by considering the misconduct happened, they tend to release the offenders and that bring the courage to students in repeating the offenses. In this view, a firm policies and actions are required to slowly prevent the norms in some academic institutions. 


\section{Lack of Critical Thinking}

Critical thinking may be applied in referencing as well as rephrasing the original contents with credits, and tendency of plagiarizing by students in a way of presenting other works as their own is caused by failure in improving and applying integral questioning skills that is essential for university students. Less proficiency and academic skills of students causing frequent plagiarism and cheating where students are too dependent on the internet and completely utilize the sources without making any studies. They are too spoon-fed by the easy access of sources and sometimes not realizing they tend to plagiarized accidentally or with purpose. While during carrying out the assignments, process of learning such as generating idea or brainstorming and a depth understanding of sources are involved and this require critical thinking of the students. Students need to motivate themselves and academics have to give full support in assisting them on how to be a student with integrity and honesty regardless of any concepts.

\section{Academic Reputation}

Teachers normally have little tolerance for plagiarism due to the fact they want the students to learn and earn the grades with their own effort and integrity. Plagiarism incidents can additionally decrease probabilities of obtaining suitable referrals from instructors for scholarship applications, overseas find out about programs, graduate schools, internships or graduate assistants. In addition, title can be cancelled if students consequently copy a primary source project, a thesis or a dissertation. To prevent this, institutions should keep the student's records and instructors to share records informally. Students are seen as cheater if the they get involve in plagiarism and that defame their honor. And most important, affect the student's future for example in furthering studies and in seeking job. And for that, academics with high concern and responsibility will ensure the students will not be repeating the plagiarism. All in all, plagiarism will have impacted the students themselves as well as education (UKEssays, 2003).

How to deal with the issue? In order to support and facilitate academic honesty, there is a set of policies and practices at all levels;

\section{Institutional Department Level}

It is very important for institutional to have the highest concern on the plagiarism issue among the student to build the academic integrity. In one of college in Mexico, paraphrasing skills has being pointed out as one of the skills required and need to be improved. CortesVera, J. (2017) said that a student not only need to know how to paraphrase in their writing but also by their verbal communication effectively and fully with ethic. As the institutional department level got the major right to control the whole students, they can come out with student handbooks which all the standards and procedures that address the academic honesty and integrity been recorded in written documentation and been disseminate to the students and the other (Wheeler and Anderson, 2010). This handbook is able to pull out the best practice and able to present the academic honesty in both direct and indirectly to serve better support to students' writing and make plagiarism are less viable or attractive option. This handbook is actually the basis communication between the education department and the students. Throughout the interaction between academician and students and also from their submission will reveal the general difficulties faced by the students. 
So from that, the department level will be able to brainstorming what are the further strategies that can be implemented and useful to make plagiarism is less had been used. Wheeler and Anderson, (2010) continues that all the concern about academic honesty and integrity can be displayed to all by warnings, by information dissemination and also clear instructions to the students. What can be added on, run the penalty seriously, not only warning. The penalty as example, repeat the subject for the first and second time, and repeat the semester for the third times. Students nowadays not really highly concern about warning with applying it. From department level, as it is continually being addressed as the professionally offensive and inappropriate, there are several activities or program had been suggested to apply in order to prevent the theft or misused ideas and words. Since it is clearly that plagiarism is not a new issue in an academic field that it often being the highlights among students, in almost over two decades, libraries play their role in educating students about the plagiarism and other activities that considered as the academic misconduct through many forms of information dissemination (Bell, S.2018). As an example from the library department, the provision of the workshop on research skills and academics procedures. It can be open as literacy class as well to the students and also academician. Cortes-Vera, Garcia and Gutierrez (2017) stated that through information literacy programs, students are taught and addressed with the ethical and honest use of information that it would develop the students' knowledge on copyright issues and encourage them to respect the copyright works. In addition, information literate students would then understood the information use and access ethically and legally in the economic, legal, and social issues. In Turn-It-In is plagiarism detection software is an act as defender against the plagiarism and also as protection to accidental plagiarism happen. It had been as very effective but unfortunately not an open access.

As other alternative, there have several web-based plagiarism detection software and proved as acceptable alternatives. Stevens (2016) mentioned that there are more than 400,000 results of plagiarism detection sites that teachers and students can use, especially in aiding the students to re-check their own work before submit. By this way, it also encourage students to be more responsibility of what they have done, attentive to the quality of referencing techniques and uphold the original assignment which ensure the quality of work as a student. In the other hand, approach from the department level that can be applied are the mandatory workshop and master classes on about the academic writing and plagiarism to all the students. It can be slightly designed the learning context in a way to motivate, participate encouragement and also the attention triggered. It is necessary that collaboration should be done in designing effective activities that provide skills of writing and referencing among students whether through the information literacy programs or any other course which obviously provide the best learning experience for the students (Cortes-Vera et al., 2017).

\section{Course level}

Some of the important component in all education course is academic writing skills (Wheeler and Anderson, 2010). But referencing skills not really have been emphasized. It actually can be applied and be applied as one of the teaching syllabus in specific course and then constantly reinforced throughout the programme. From our thought, we would suggest to reinforce reference skill class as one of mandatory class. In addition, they said that students have the right to submit and get the feedback for their first draft of their paper and this is able to help in detection plagiarism either deliberately or accidental at the early stage before 
proceed. It is beneficial to the students in order to get remarks or comment from their lectures before submission. They also mentioned that as a last warning to the students and last way to prevent the plagiarism in the student's writing, in their assignment submission, they are needed to sign the declaration saying that their work is originally by them and acknowledge all the sources that have been used. The declaration must clearly state the penalty if they are ignored the declaration. Each of the courses also can make mandatory demand to each student to run through their assignments using Turn-It-In and encourage them to learn how to do reference for each idea that have been used in their tasks.

\section{Faculty and Input}

In a faculty, the entire academician can be considered as an English teacher regardless of their course allocation. this is because of their ESL (English as Second Language) teaching qualifications and experiences and also the recognition the importance if language as the transmission for the idea generating (Wheeler and Anderson, 2010). The approach for teaching both content and also language elements are needed in order to deliver content to the students that is struggling with the unfamiliar of the content and language. It means that the academician need to take seriously about their role as academic integrity defender and keep vigilantly check and monitor the student's output.

They said that this activity indirectly able to increase the awareness among the students about the appropriate academic writing processes and also to reduce the misused the idea or words written by others. Throughout the education process, the social and community aspect need to be concerned and give more attention to the faculty. In society, this thing probably less value on an individual but it does on the cooperation and social cohesion. The faculty need to explain and disseminate the input about the students need to aware by their responsibility and really understand that they not only have their right but to act towards the inappropriately help asking by their family or peers. Without this awareness among the students, the amount of education or punishment cannot be done and the academic integrity will be drop. Faculty also can organize reference skill quizzes or competition during Language Festival. It is able to help students to gain more knowledge about reference in a more competitive way.

\section{Student Involvement}

In education, the student themselves need to active in participating their own learning. Wheeler and Anderson, (2010) mentioned that they are able to get clarification by asking question on any parts that they are not fully comprehend as documentation for each of the assessment procedures and being crystal clear. Being ignorance is no defense for malpractice, so all the expectation or consequences need to be addressed in multiple ways. In student life, the first draft submitting for their written task is the first crucial aspect. Even though this is universal permitted and can be scheduled, but it is not usually being awarded any marks and are not always have been demanding, so, at the end, this is actually back initiative from the students themselves either to gain benefit of their right to get feedback for draft submission. Students also need to be more actively and aggressive in learning progress. Somehow, from freeware or online, students are able to run their tasks and get check their plagiarism similarity. Students may also develop their own initiative to detect their own mistakes as to avoid plagiarism either it is intentionally or unintentionally. Eisa, Salim, \& Alzahrani, (2015) stated that there are some features to detect the plagiarism listed and the top and often been used features are the top keyword, the similarity on first sentence, and query phrase. These 
features using stemming process where the most using words that appeared in document are considered as ideas in papers. Besides that, there is also semantic features where it can be identified as plagiarism through synonyms, antonyms, and the meanings of the texts within the sentences throughout the whole document.

\section{Conclusion}

Clearly, process of learning might take some time however students need to learn and majoring proper academic writing. Academic institutions are the fundamentals in the upskills student's competency as well as in an academic integrity establishment. Accurate terminology and firm penalties somehow are the factors of less plagiarism issues while the consequences of plagiarism should be imparted among students and academics in order to achieve zero issues in academic misconducts. Concerns on student's behavior and motivation should also be highlighted in academic institutions that it is among the factors that affect their quality performance in academic. Proper punishment is necessary to be included among the penalties to the academic misconduct as a reminder and warning to the students and it should be taken seriously by both students and academic institution. Achievement in high quality outputs in academic produce excellent students with intelligent and proficiency. Understanding and accomplishing results based on what is already defined as well as anticipating the academic environment in advance is important as work environment (Šprajc et al., 2017). Achieving the basic and most vital mission of knowledge transmission is the main goals that all parties of academic world should emphasize on.

\section{Acknowledgement}

This article is financially supported by:

1. Faculty of Information Management, UiTM Selangor, Malaysia

2. Advanced Analytics Engineering Center (AAEC), UiTM Malaysia

\section{Corresponding Author:}

Saiful Farik Mat Yatin.

Email: farik@uitm.edu.my

\section{References}

Bell, S. (2018). Addressing student plagiarism from the library learning commons. Information and Learning Science, 119(3-4), 203-214. https://doi.org/10.1108/ILS10-2017-0105

Cortes-Vera, J., Garcia, T. J., \& Gutierrez, A. (2017). Knowing and improving paraphrasing skills of Mexican college students. Information and Learning Science, 118(9-10), 490-502. https://doi.org/10.1108/ILS-05-2017-0042

Syahrani, D., Yusof, M. (2009). A Different Perspective on Plagiarism. Retrieved from http://iteslj.org/Articles/Yusof-Plagiarism.html

Eisa, T. A. E., Salim, N., \& Alzahrani, S. (2015). Existing plagiarism detection techniques: A systematic mapping of the scholarly literature. Online Information Review, 39(3), 383-400. https://doi.org/10.1108/OIR-12-2014-0315

Marshall, S., \& Garry, M. (2005). How well do students really understand plagiarism? ASCILITE 2005 - The Australasian Society for Computers in Learning in Tertiary Education, 457-467. Retrieved from https://www.scopus.com/inward/record.uri?eid=2-s2.0- 
77952201476\&partnerID=40\&md5=09fc8d1ee02b7113c066766d73b2b015

Šprajc, P., Urh, M., Jerebic, J., Trivan, D., \& Jereb, E. (2017). Reasons for plagiarism in higher education. Organizacija, 50(1), 33-45. https://doi.org/10.1515/orga-2017-0002

Stevens, A. (2016). A Short-List of Digital Plagiarism Detection Sites | Articles | Publications | Profweb. Retrieved July 6, 2018, from http://www.profweb.ca/en/publications/articles/a-short-list-of-digital-plagiarismdetection-sites

UKEssays. (2013). Effect of Plagiarism in University.

Retrieved from https://www.ukessays.com/essays/english-language/effect-of-plagiarismin-university-english-language-essay.php?vref=1

Wheeler, D., \& Anderson, D. (2010). Dealing with plagiarism in a complex information society. Education, Business and Society: Contemporary Middle Eastern Issues, 3(3), 166-177. https://doi.org/10.1108/17537981011070082

Wilkinson, J. (2009). Staff and Student Perceptions of Plagiarism and Cheating. International Journal of Teaching and Learning in Higher Education, 20(2), 98-105. Retrieved from http://www.isetl.org/ijtlhe/articleView.cfm?id=278 